ISSN: 1979-7362

\title{
Uji Kinerja Mesin Pemecah Kulit Gabah (Husker) Tipe Rol Karet pada Penggilingan Gabah Kecil
}

\author{
Diah Pramana Mulyawan ${ }^{1}$, Iqbal ${ }^{1}$ dan Ahmad Munir ${ }^{1}$ \\ 1)Program Studi Teknik Pertanian, Universitas Hasanuddin Makassar
}

\begin{abstract}
ABSTRAK
Penggilingan gabahsangat berperan nyata dalam memajukan perberasan nasional. Mutu beras yang rendah dan harga yang fluktuatifcenderung tidak memberikan insentif kepada petani. Tingginya kebutuhan akan beras, menyebabkan kebutuhan alat mesin pertanian pun meningkat. Mesin pengupas gabah yang banyak dipakai dewasa ini adalah tipe roll karet. Adapun tujuan dari penelitian ini yaitu untuk menghitung efesiensi mesin pemecah kulit gabah (husker) dan mengetahui mutu beras. Penelitian ini juga bertujuan untuk menghitung rendemen yang dihasilkan dari mesin pemecah kulit gabah (husker).Penelitian dilakukan, dilokasi penggilingan gabah kecil yang bertempat di kelurahan laikang, kecamatan biringkanaya, makassar, sulawesi selatan.Pada penelitian ini dilaksanakan dalam beberapa tahap diantaranya tahap pengumpulan alat dan bahan. Parameter untuk menganalisis kapasitas giling, mutu beras dan rendemen beras dilakukan pengamatan untuk bobot gabah yang akan digiling, bobot beras hasil gilingan, dan waktu menggiling gabah menjadi beras. Berdasarkan hasil pengolahan data didapatkan bahwa nilai rendemen giling meningkat pada kecepatan putaran $1354 \mathrm{rpm}$. Hasil dari efisiensi pengupasan pada kecepatan putaran mesin $1237 \mathrm{rpm}$ persentase rata-rata efisiensi pengupasan 46,3\%, pada rpm 1354 diperoleh hasil rata-rata efisiensi pengupasan berkisar 46,7\% dan pada kecepatan putaran mesin $1395 \mathrm{rpm}$ diketahui persentase rata-rata efisiensi pengupasan $46,6 \%$.Mutu beras yang dihasilkan dari kualitas pengupasan pada kecepatan putaran mesin $1237 \mathrm{rpm}$ persentase butir utuh 70,03\%, butir patah $3,58 \%$, butir menir $1,51 \%$. Persentase butir utuh pada kecepatan putaran 1354 rpm yaitu $67,75 \%$, butir patah $5,16 \%$ dan butir menir 2,89\%. Sedangkan pada kecepatan putaran mesin $1395 \mathrm{rpm}$ persentase butir patah 56,26\%, butir patah 4,80\%, butir menir 1,27\%.Mutu gabah yang diperoleh dari pengamatan derajat kebersihan gabah butir hijau termasuk kategori mutu III, butir kuning termasuk mutu IV, butir rusak mutu IV, butir asing mutu IV dan butir kapur termasuk kategori mutu II. Dari hasil tersebut dapat disimpulkan bahwa standar mutu pada kecepatan putaran 1237 rpm termasuk mutu beras paling baik.
\end{abstract}

\section{Kata kunci: penggilingan gabah, efisiensi husker, mutu beras, rendemen}

\section{PENDAHULUAN}

\section{Latar Belakang}

Padi merupakan komoditas strategis yang secara langsung mempengaruhi kehidupan sebagian besar penduduk Indonesia, oleh karena itu program peningkatan produksi padi mendapat prioritas utama dari pemerintah untuk mewujudkan ketahanan pangan dan kesejahteraan petani. Mutu yang dihasilkan padi menjadi beras nantinya akan sangat berpengaruh bagi petani untuk nilai penjualan beras.

Kurangnya sumber daya manusia dan sumber daya alam yang semakin tidak mendukung seiring berkurangnya lahan pertanian serta daerah resapan air, membuat sektor pertanian khususnya budidaya padi di Indonesia mulai mengalami penurunan kualitas produksi.Untuk mengatasi kekurangan tenaga pada usaha produksi padi, perlu dikembangkan alat mesin pertanian untuk membantu pekerjaan petani guna untuk 
meningkatkan produksi beras dalam negeri, misalnya adalah Rice Milling Unit (RMU).RMU merupakan alat mesin pertanian yang difungsikan untuk menggiling gabah menjadi beras. Dengan menggunakan RMU, penggilingan gabah menjadi lebih cepat dibandingkan dengan cara manual atau ditumbuk.

Menurut Sugondo (2002) ada dua faktor penting untuk mendapatkan mutu dan rendemen giling yang tinggi. Pertama, mutu gabah padi termasuk kadarair, jumlah kotoran/benda asing, jumlah gabah retak/patah, jumlah gabah muda, jumlah gabah rusak, dan jumlah gabah varietas lain. Faktor kedua, yaitu sarana mekanis/mesin penggilingan padi yang dipakai, terutama jenis mesin dan mekanisme kerja serta komposisi atau konfigurasi mesin. Selain itu, rendemen dan mutu beras giling yang dihasilkan erat kaitannya dengan justifikasi mesin.

Masalah besar petani adalah kehilangan hasil, mutu yang rendah dan harga yang fluktuatif yang cenderung tidak memberikan insentif kepada mereka sangat amat dirasakan dan perlu segera solusinya. Tingginya kebutuhan akan beras, menyebabkan kebutuhan alat mesin pertanian pun meningkat, guna memenuhi kebutuhan pengolahan pascapanen padi. Salah satu alat mesin pengolah pasca panen padi yang banyak terdapat dimasyarakat adalah penggiling padi atau Rice Milling Unit (RMU). (Sovan, 2002).

Teknologi memproses beras pada umumnya dilakukan dengan cara tumbukan yang berulang-ulang oleh palu kayu yang digerakkan oleh kincir dengan sumber penggeraknya air. Proses ini tidak efisien karena rendemen rendah dan kadar beras pecah yang dihasilkan tinggi, dan waktu yang digunakan lama. Teknologi pemproses beras ditingkatkan dengan sistem pengupas sekaligus penyosoh dengan menggunakan silinder, memasang alat pengupas tipe roll karet (rubber-roll husker), dan dilengkapi alat penghembus sekam dengan menggunakan blower sehingga diperoleh rendemen kurang dari $60 \%$ menjadi $63,4 \%$ serta persentase beras kepala menjadi lebih tinggi. (Tahir, 1992).

Penggilingan gabah sebagai basis pertanian sangat berperan nyata dalam memajukan perberasan nasional mendukung swasembada dan ketahanan pangan nasional. Penggilingan padi menyerap dan mengolah gabah dari petani menjadi beras, jika tidak ada penggilingan padi maka besaran angka ketersediaan beras tidak dapat dihitung karena gabah tidak dapat diolah menjadi beras secara optimal dan diedarkan di pasaran.

Secara umum, mesin-mesin yang digunakan dalam usaha industri jasa penggilingan padi adalah mesin pemecah kulit/sekam, (huller atau husker), mesin pemisah gabah dan beras pecah kulit (brown rice separator), mesin penyosoh atau mesin pemutih (polisher). Mesin pengupas gabah yang banyak dipakai dewasa ini adalah tipe roll karet. Dewasa ini, sistem roll karet sering ditemukan pada unit mesin penggiling gabah. Masingmasing pabrik membuat model dengan spesifikasi tertentu. Pada dasarnya tipe mesin ini terdapat dua buah roll karet yang berputar berlawanan arah. Salah satu roll berada pada posisi yang tetap yang disebut roll utama yang berkecepatan tinggi dan sebuah roll pembantu yang berkecepatan rendah yang posisinya dapat diatur untuk mendapatkan jarak antara kedua roll sesuai dengan keinginan.

Berdasarkan uraian di atas maka dilakukanlah penelitian uji kinerja terhadap mesin pemecah kulit gabah (husker) tipe rol karet.

\section{Tujuan dan kegunaan}

Tujuan penelitian ini adalah untuk menghitung efesiensi mesin pemecah kulit gabah (husker) dan mengetahui mutu beras serta rendemen yang dihasilkan dari mesin pemecah kulit gabah (husker).

Kegunaan dari penelitian ini ialah sebagai bahan pertimbangan dalam 
pengembangan mesin pemecah kulit gabah (husker) kedepannya.

\section{METODOLOGI PENELITIAN}

\section{Waktu dan Tempat}

Penelitian ini dilaksanakan pada bulan September 2017.Kelurahan Laikang, Kecamatan Biringkanaya, Makassar, Sulawesi Selatan.

\section{Alat dan Bahan}

Alat yang digunakan dalam penelitian ini adalah mesin pemecah kulit (rice milling unit) tipe roll karet, timbangan, stopwatch, moisture tester, tachometer.

Bahan yang digunakan pada penelitian ini adalah gabah dari varietas ciherang.

\section{Prosedur Penelitian}

Penelitian ini dilaksanakan dalam beberapa tahap diantaranya tahap pengumpulan alat dan bahan. Parameter untuk menganalisis kapasitas giling, mutu beras dan rendemen beras dilakukan pengamatan untuk bobot gabah yang akan digiling, bobot beras hasil gilingan, dan waktu menggiling gabah menjadi beras.

Menurut SNI (1989), persamaan yang digunakan untuk kapasitas kupas, rendemen giling, efisiensi pengupasan, kualitas pengupasan, derajat kebersihan gabah, keadaan rata-rata BPK pada gabah, dan kecepatan keliling sesuai dengan prosedur berikut:

1. Pelaksaan Pengujian

a. Kapasitas Kupas

1. Sediakan gabah sebanyak $20 \mathrm{~kg}$ setiap satu kali penggilingan.

2. Gabah dimasukkan kedalam alat dalam keadaan corong umpan (hopper) tertutup.

3. Setelah mesin pengupas berjalan pada kecepatan operasional, hopper dibuka dan rol distel kembali pada posisi dimana daya pengupasan tertinggi.
4. Setelah daya pengupasan berjalan lancar dan stabil, BPK ditampung dalam satuan waktu tertentu (tergantung kapasitas mesin yang akan diuji) kemudian ditimbang. Perhitungan:

Kapasitas kupas $\mathrm{K}=\frac{B k}{t}$

Dimana:

$\mathrm{K}$ : kapasitas kupas (kg/jam)

$\mathrm{Bk}$ : berat BPK yang dihasilkan $(\mathrm{kg})$

$\mathrm{t}$ : waktu yang dibutuhkan (jam)

b. Rendemen Giling

Perhitungan :

$R(\%)=\frac{\text { BTBdihasilkan }}{B G K G} \times 100 \%$

Dimana:

BTB dihasilkan: Berat total beras yang dihasilkan $(\mathrm{kg})$

BGKG: Berat gabah kering giling $(\mathrm{kg})$

c. Efisiensi Pengupasan

Perhitungan:

Efisiensi pengupasan $=$

$\frac{\text { beratBPK }}{\text { berat } B P K+\text { beratgabah }} \times 100 \%$

d. Kualitas Pengupasan

1. Ambil sampel sebanyak \pm 100 gram.

2. Pisahkan antara beras pecah kulit utuh, patah, menir dan gabah tak terkupas.

3. Timbang masing-masing dari beras pecah kulit tersebut.

4. Pengujian dilakukan sebanyak 9 kali ulangan.

Perhitungan:

Bs $=\frac{B m}{B c} \times 100 \%$

Dimana:

$B_{S}=$ persentase masing-masing bagian (\%)

$B_{m}=$ berat bagian yang bersangkutan (gram)

$B_{c}=$ beratsampel (gram)

2. Cara Hitung Kondisi Uji

a. Kadar Air

1. Ambil sampel sebanyak \pm 5 gram gabah. 
2. Penetapan kadar air disesuaikan dengan cara kerja alat pengukur kadar air yang digunakan.

3. Dilakukan pengulangan sebanyak 9 kali.

b. Derajat Kebersihan Gabah

1. Ambil sampel sebanyak 100 gram gabah.

2. Kupas sampel gabah tersebut.

3. Pisahkan antarabutir kapur, butir rusak/kuning, butir asing, dan butir hijau.

4. Timbang masing-masing bagian tersebut.

Perhitungan :

Bs $=\frac{B m}{B c} \times 100 \%$

Dimana :

$$
\begin{aligned}
B_{s}= & \text { persentase masing-masing } \\
& \text { bagian }(\%) \\
B_{m}= & \text { berat komponen yang } \\
& \text { bersangkutan (gram) } \\
B_{c}= & \text { berat sampel (gram) }
\end{aligned}
$$

c. Kecepatan Keliling

Kecepatan keliling roda pengupas dihitung dengan rumus:

$\mathrm{V}=\frac{d n}{60}$

Dimana:

$\mathrm{V}$ : kecepatan keliling (m/sekon)

$\mathrm{d}$ : diameter rol pengupas (m)

$\mathrm{n}$ : kecepatan putaran roda pengupas (rpm)

\section{Bagan Alir Penelitian}

Penelitian ini dilakukan dengan menggunakan bagan alir sebagai berikut:

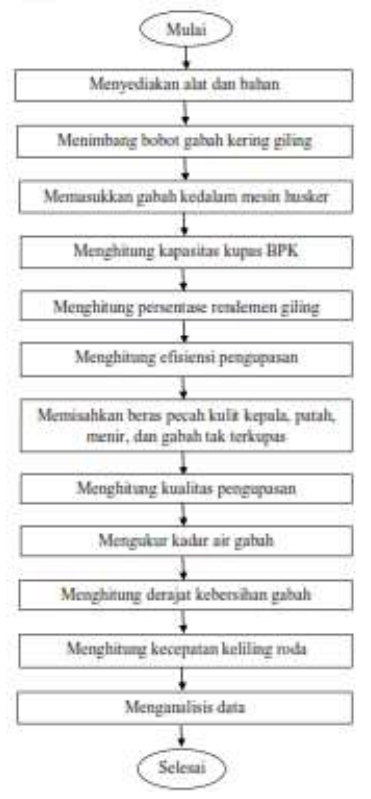

\section{HASIL DAN PEMBAHASAN}

\section{Derajat Kebersihan}

Dari proses pengujian mesin pemecah kulit hasil yang diharapkan dari derajat kebersihan gabah yaitu sedikitnya nilai persentase dari butir hijau, butir kuning, butir rusak, butir asing, butir kapur, sekam, dan sisa beras pecah kulit (BPK) yang telah diamati. Berdasarkan pada Gambar 1.

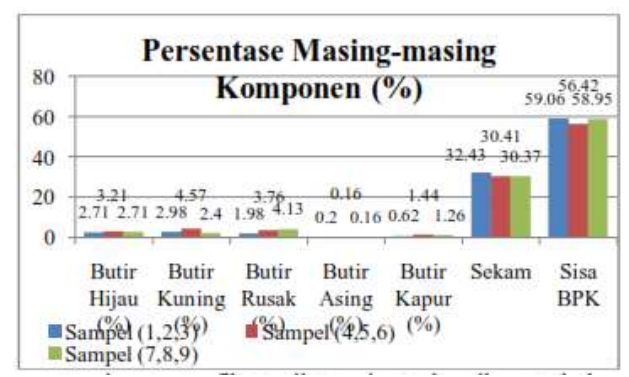

Gambar 1. Grafik Hasil Derajat Kebersihan Gabah

Dapat dilihat dari rata-rata hasil persentase pada sampel 1,2,3 diperoleh 2,71\% butir hijau, butir kuning 2,98\%, butir rusak 1,98\%, butir asing 0,20\%, persentase butir kapur 0,62\%, sekam $32,43 \%$, dan butir beras yang tersisa 
59,06\%. Pada sampel 4,5,6 didapatkan rata-rata persentase butir hijau, butir kuning, butir rusak meningkat menjadi $3,21 \%$ butir hijau, $4,57 \%$ butir kuning, 3,76 butir rusak, persentase butir asing $0,16 \%$, butir kapur $1,44 \%$, sekam 30,41\%, dan butir beras yang tersisa sebanyak $56,42 \%$. Sedangkan pada sampel 7,8,9 diperoleh hasil rata-rata butir hijau 2,71\%, persentase butir kuning 2,40\%, butir rusak $4,13 \%$, butir asing $0,16 \%$, butir kapur $1,26 \%$, sekam $30,37 \%$, dan butir beras yang tersisa $58,95 \%$. Terjadinya butir hijau, butir kuning, butir rusak, dan butir kabur pada gabah disebabkan karena pengaruh kadar air yang tinggi dan dipengaruhi oleh kualitas gabah yang akan diproses. Hal ini didukung oleh hasil penelitian Prihadi et all (2009) tinggi rendahnya butir mengapur maupun butir kuning/rusak dipengaruhi oleh kualitas gabah yang diproses. Gabah yang belum masak optimum atau tidak matang serempak, dan terjadinya fermentasi gabah akibat terlambatnya proses pengeringan menyebabkan beras giling yang dihasilkan mengandung kapur, berwarna kuning kecoklatan, dan ada bercak hitam.

Berdasarkan pemutuan beras oleh BSN (2008) butir hijau termasuk kategori mutu III, butir kuning termasuk mutu IV, butir rusak mutu IV, butir asing mutu IV dan butir kapur termasuk kategori mutu II.

\section{Kapasitas Kupas}

Penentuan kapasitas kupas yaitu untuk mengetahui berapa lama waktu yang digunakan selama proses penggilingan dan kapasitas atau bobot beras pecah kulit (BPK) yang dihasilkan setelah penggilingan. Salah satu hal yang harus diperhatikan selama proses penggilingan gabah berlangsung yaitu, gabah yang dimasukkan kedalam corong umpan (hopper) harus dalam keadaan tertutup sehingga pada saat mesin pengupas dinyalakan hopper kemudian dibuka bersamaan dengan dilakukan penghitungan waktu. Sedangkan varietas gabah yang digunakan dalam penelitian ini hanya satu jenis, yaitu gabah varietas ciherang. Penelitian yang telah dilakukan sebanyak 3 kali ulangan pada setiap kecepatan putaran mesin dengan menggunakan kecepatan putaran mesin $1237 \mathrm{rpm}, 1354 \mathrm{rpm}$, dan $1395 \mathrm{rpm}$.

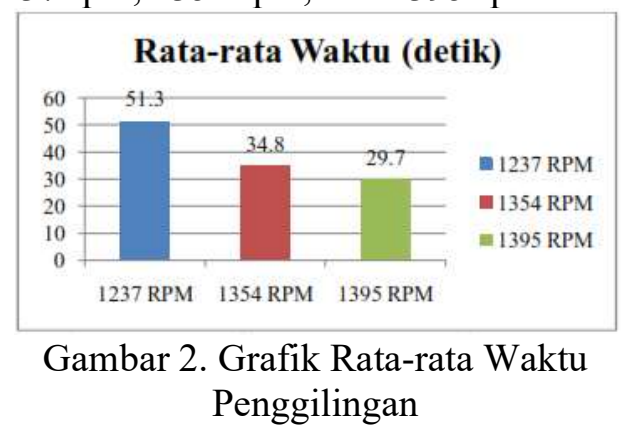

\section{Kapasitas Pengupasan} (kg/jam)

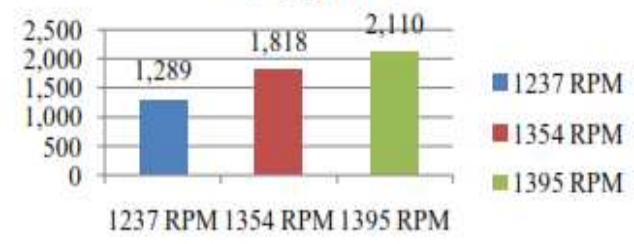

Gambar 3. Grafik Hasil Kapasitas Pengupasan

Berdasarkan hasil pada pengujian pertama menggunakan kecepatan putaran 1237 rpm rata-rata waktu yang dibutuhkan 51,3 detik diperoleh kapasitas pengupasan $1.364 \mathrm{~kg} / \mathrm{jam}$. Pada pengujian kedua kecepatan putaran mesin 1354 waktu yang dibutuhkan rata-rata 34,8 detik diperoleh kapasitas pengupasan $1.962 \mathrm{~kg} / \mathrm{jam}$. Kemudian pada rpm 1395 rata-rata waktu yang dibutuhkan 29,7 detik untuk memperoleh kapasitas pengupasan 2.183 $\mathrm{kg} / \mathrm{jam}$. Dapat dilihat pada gambar 9 . bahwa pada kecepatan putaran mesin 1395 waktu yang dibutuhkan lebih singkat dalam melakukan proses pengupasan sehingga kapasitas pengupasan yang dihasilkan meningkat, sebaliknya pada kecepatan putaran mesin 1237 rpm waktu proses pengupasan yang dibutuhkan lebih lama sehingga kapasitas kupas yang 
dihasilkan lebih sedikit. Hal ini dipengaruhi oleh kecepatan putaran mesin dan jarak antara kedua roll karet. Pernyataan ini sesusai dengan hasil penelitian Khairul, et all (2014) bahwa semakin kecil jarak renggang rol karet maka beras pecah atau beras yang terkelupas semakin banyak. Dan apabila jarak renggang rol karet semakin besar maka gabah yang dihasilkan juga akan semakin banyak. Pada kecepatan putaran $1354 \mathrm{rpm}$ diperoleh hasil rata-rata berat BPK yaitu 17,5 kg dan rata-rata berat BPK pada rpm 1395 menurun menjadi 17,4. Hal ini terjadi karena pada kecepatan putaran 1354 rpm memiliki banyak gabah yang hampa atau gabah tidak berisi. Hal ini sesuai dengan hasil rendemen giling pada gambar 11. bahwa nilai rendemen di kecepatan putaran $1354 \mathrm{rpm}$ lebih tinggi dibandingkan kecepatan putaran $1395 \mathrm{rpm}$.

Berdasarkan tabel Uji Anova dihasilkan nilai probabilitas $0.014<0,05$ yang berarti bahwa terdapat perbedaan secara signifikan pada kecepatan putaran mesin terhadap kapasitas pengupasan. Karena adanya perbedaan secara signifikan, maka dilanjutkan dengan uji beda nyata jujur. Berdasarkan tabel Tukey HSD (Uji Beda Nyata Jujur), dapat dilihat bahwa pada kecepatan 1237 RPM dengan 1354 RPM dan 1354 RPM dengan 1395

RPM tidak terdapat perubahan kapasitas pengupasan yang signifikan. Sedangkan pada kecepatan 1237 RPM dengan 1395 RPM terdapat perubahan kapasitas pengupasan yang signifikan.

\section{Rendemen GilingBeras Pecah Kulit}

Pengujian dengan menghitung rendemen giling dapat diketahui setelah dilakukan proses penggilingan gabah. Pada perlakuan pertama dengan menggunakan kecepatan putaran $1237 \mathrm{rpm}$ dapat dilihat Gambar 11.

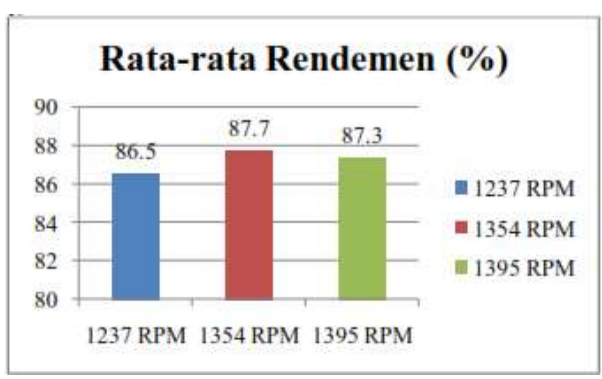

Gambar 11. Grafik Hasil Rendemen Giling Beras Pecah Kulit

Persentase nilai rendemen giling diperoleh rata-rata $86,5 \%$, perlakuan kedua pada kecepatan putaran 1354 rpm persentase rendemen meningkat menjadi $87,7 \%$, dan pada perlakuan ketiga menggunakan kecepatan putaran mesin $1395 \mathrm{rpm}$ diperoleh hasil rata-rata rendemen giling yaitu $87,3 \%$. Pada kecepatan putaran mesin 1237 rpm mengalami perbedaan nilai yang berbeda jauh dibandingkan pesentase nilai kecepatan putaran mesin $1354 \mathrm{rpm}$ dan 1395 rpm. Hal ini disebabkan karena kecepatan putaran mesin pada perlakuan pertama belum berjalan kontinyu, jadi hasil persentase kecepatan putaran $1237 \mathrm{rpm}$ nilai rendemennya berbeda jauh dengan rpm 1354 dan rpm 1395. Pernyataan ini sesuai dengan hasil penelitian Damardjati et al., 1981 dalam Rokhani (2007), rendemen giling sangat tergantung pada bahan baku gabah, varietas, derajat kematangan, dan cara penanganan awal (pre handling) serta tipe dan konfigurasi mesin penggiling. Sedangkan pada kecepatan putaran mesin 1354 nilai rendemen $87,7 \%$, setelah kecepatan putaran dinaikan persentase rendemen menurun menjadi 87,3\%. Menurut Nofriadi (2007) bahwa kecepatan putaran mesin mempengaruhi hasil rendemen hal ini sesuai dengan pengaruh putaranterhadap rendemen karena semakin cepat putaran mesin maka tekanan yang terjadi pada gabah semakin besar. Semakin cepat kecepatan putaran mesin, maka semakin kecil waktu kontak dengan butir gabah, sehingga kulit gabah yang terkelupas tidak begitu banyak. 
Berdasarkan tabel Uji Anova dihasilkan nilai probabilitas $0.873>0,05$ yang berarti bahwa tidak terdapat perbedaan secara signifikan pada kecepatan putaran mesin terhadap hasil rendemen giling.

\section{Efisiensi Pengupasan}

Nilai efisisensi pengupasan menunjukkan persentase gabah yang berhasil dikupas saat proses penggilingan dengan menghitung bobot BPK dan bobot gabah sebelum dilakukan pengujian. Berdasarkan hasil perhitungan efisiensi pengupasan dapat dilihat pada gambar 12 .

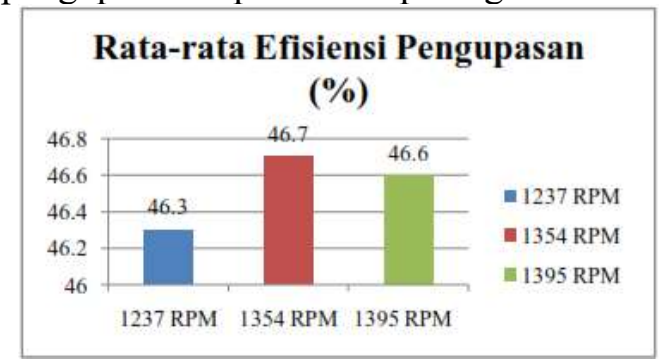

Gambar 4. Grafik Hasil Efisiensi

Pengupasan

Dapat diketahui bahwa pada kecepatan putaran mesin 1237 rpmpersentase rata-rata efisiensi pengupasan 46,3\%, pada rpm 1354 diperoleh hasil rata-rata efisiensi pengupasan berkisar $46,7 \%$, dan pada kecepatan putaran mesin $1395 \mathrm{rpm}$ diketahui persentase rata-rata efisiensi pengupasan 46,6\%. Dapat dilihat hubungan nilai efisiensi pengupasan pada rpm 1354 dan rpm 1395 nilainya tidak berbedah jauh, disebabkan karena kecepatan putaran mesin juga tidak terlalu meningkat. Hal yang mempengaruhi efisiensi pengupasan yaitu jarak antara kedua roll dan kecepatan putaran mesin. Hal ini didukung oleh hasil penelitian Waries (2006) bahwa semakin cepat putaran mesin maka semakin tinggi nilai efisiensi pengupasan, tapi di satu sisi semakin tinggi pula persentase beras patahnya. Menurunnya nilai efisiensi pengupasan pada kecepatan putaran 1395 rpm disebabkan semakin tinggi kecepatan putaran mesin maka semakin sedikit waktu kontak dengan butir gabah, sehingga proses pemecahan sekam sebentar.

Berdasarkan tabel Uji Anova dihasilkan nilai probabilitas $0.881>0,05$ yang berarti bahwa tidak terdapat perbedaan secara signifikan pada ketiga kecepatan putaran mesin terhadap hasil efesiensi pengupasan.

\section{Kualitas Pengupasan}

Pengujian pada mesin pemecah kulit gabah yaitu untuk mengetahui kinerja mesin yang akan dihasilkan. Kualitas pengupasan dapat diketahui dengan cara mengamati butir (butir utuh, gabah yang tidak terkupas, butir patah, dan butir menir) hasil akhir dari proses penggilingan. Contoh sampel yang akan diamati berjumlah 100 gram, sampel diambil secara acak pada gabah hasil penggilingan.

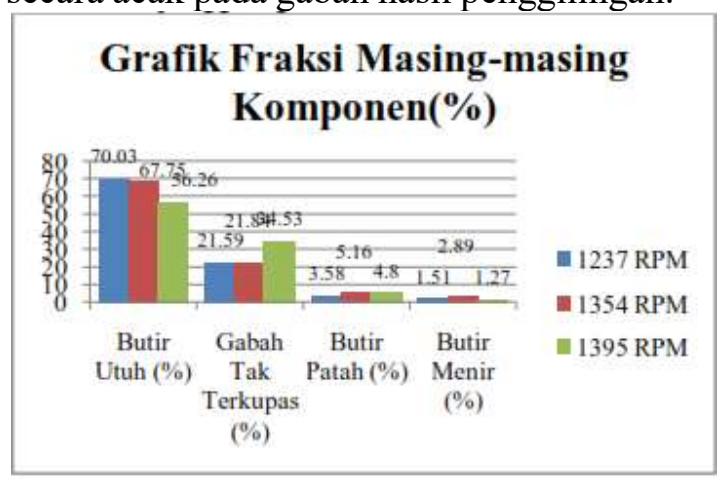

Gambar 5. Grafik Fraksi Masing-masing Komponen

Berdasarkan pada gambar 5. Dapat dilihat bahwa kualitas dari hasil pengupasan menggunakan kecepatan putaran mesin $1237 \mathrm{rpm}, 1354 \mathrm{rpm}$, dan $1395 \mathrm{rpm}$ menghasilkan persentase butir utuh rata-rata $70,03 \%, 67,75 \%$, dan $56,26 \%$ persentase butir utuh semakin menurun setiap meningkatnya kecepatan putaran mesin. Sebaliknya, hasil persentase rata-rata gabah yang tidak terkupas pada kecepatan putaran mesin $1237 \mathrm{rpm}, 1354 \mathrm{rpm}$, dan $1395 \mathrm{rpm}$ mengalami peningkatan nilai setiap meningkatnya kecepatan putaran mesin 
menjadi $21,59 \%, 21,84 \%$, dan $34,53 \%$. Hal ini berhubungan dengan kecepatan putaran mesin. Meningkatnya angka kadar air pada kecepatan putaran 1395 rpm menyebabkan meningkatnya nilai persentase gabah yang tidak terkupas. Hal ini disebabkan pada kadar air yang tinggi, menyebabkan gabah sulit dikupas sehingga banyak butir gabah yang tidak terkupas. Pada kecepatan putaran 1354 rpm butir patah dan butir menir mengalami peningkatan dibandingkan pada kecepatan putaran mesin 1395 rpm, hal ini dipengaruhi oleh kadar air yang rendah dikecepatan putaran 1354 rpm. Pada kadar air yang lebih tinggi gabah sulit dikupas, sedangkan pada kadar airyang lebih rendah butiran gabah menjadi mudah patah. Adapun penyebab dari meningkatnya persentase butir utuh, butir patah dan butir menir yaitu kadar air pada gabah.Pernyataan ini sesuai dengan hasil penelitain Patiwiri (2006) bahwa,kualitas pengupasan bergantung pada beberapa faktor, seperti jenis padi, kualitas padi, kadar air gabah, karakteristik mesin dan penyetelannya (kekerasan karet, kecepatan putaran rol, tekanan rol, lebar rol, jarak rol, jumlah bahan yang masuk, pengaturan saringan), dan keahlian operator.

Adanya butir menir pada beras giling akan berpengaruh terhadap mutu fisik beras giling. Semakin tinggi kandungan butir menir beras giling, mutu fisiknya akan semakin menurun. Beras pecah kulit (BPK) ini masih harus melewati proses penyosohan. Berdasarkan pemutuan beras oleh BSN (2008) pada kecepatan putaran mesin 1237 rpm butir utuh termasuk mutu I, butir patah termasuk mutu I dan butir menir termasuk kategori mutu I. Kemudian pada kecepatan putaran $1354 \mathrm{rpm}$ butir utuh termasuk mutu I, butir patah mutu I, dan butir menir termasuk mutu III. Sedangkan pada kecepatan putaran mesin 1395 rpm butir utuh termasuk kategori mutu II, butir patah mutu I, dan butir menir mutu II. Mutu dari beras selain disebabkan oleh gabah yang akan digiling, juga dapat dipengaruhi oleh kondisi mesin penggilingan padi itu sendiri.

Berdasarkan tabel Uji Anova dihasilkan nilai probabilitas butir utuh, gabah tak terkelupas, dan butir menir lebih dari 0,05 yang berarti bahwa tidak terdapat perbedaan secara signifikan pada kecepatan putaran mesin terhadap kualitas pengupasan (butir utuh, gabah tak terkelupas, dan butir menir). Sedangkan untuk butir patah dihasilkan nilai probabilitas $0,12<0,05$ yang berarti bahwa terdapat perbedaan secara signifikan pada kecepatan putaran mesin terhadap kualitas pengupasan (butir patah).Karena adanya perbedaan secara signifikan, maka dilanjutkan dengan uji beda nyata jujur.

Berdasarkan tabel 12. Tukey HSD (Uji Beda Nyata Jujur), dapat dilihat bahwa pada kecepatan 1395 RPM dengan 1354 RPM tidak terdapat perubahan kualitas pengupasan yang signifikan. Sedangkan pada kecepatan 1237 RPM dengan 1395 RPM dan 1237 RPM dengan 1354 RPM terdapat perubahan kapasitas pengupasan yang signifikan.

\section{Kecepatan Keliling Roda}

Pengukuran kecepatan putaran mesin dengan menggunakan tachometer untuk mengetahui kecepatan keliling roda dari mesin pemecah kulit gabah. Dari penelitian yang dilakukan diperoleh hasil kecepatan keliling roda pada kecepatan putaran $1237 \mathrm{rpm}$ yaitu, 4,32 $\mathrm{m} / \mathrm{s}$, kecepatan putaran $1354 \mathrm{rpm}$ menghasilkan kecepatan keliling 4,73 m/s dan hasil pada kecepatan putaran $1395 \mathrm{rpm}$ yaitu 4,88 $\mathrm{m} / \mathrm{s}$. Hasil tersebut sesuai dengan RPM yang diperoleh, semakin cepat kecepatan putaran mesin maka kecepatan keliling roda juga akan meningkat. 


\section{PENUTUP}

\section{Kesimpulan}

Kesimpulan yang diperoleh dari penelitian ini adalah:

1. Rendemen giling lebih baik jika menggunakan kecepatan putaran mesin $1354 \mathrm{rpm}$.

2. Efisiensi pengupasan lebih tinggi jika menggunakan kecepatan putaran mesin 1354 rpm dibandingkan dengan kecepatan putaran mesin $1237 \mathrm{rpm}$ dan $1395 \mathrm{rpm}$.

3. Kualitas pengupasan pada mesin pemecah kulit gabah lebih baik menggunakan kecepatan putaran mesin $1237 \mathrm{rpm}$.

4. Derajat kebersihan gabah sebaiknya menggunakan kecepatan putaran mesin 1237 rpm dibandingkan dengan kecepatan putaran mesin $1354 \mathrm{rpm}$ dan $1395 \mathrm{rpm}$.

\section{DAFTAR PUSTAKA}

BB Padi. 2010. Deskripsi Varietas Padi. Balai Besar Penelitian Tanaman Padi; $109 \mathrm{hlm}$.

BSN. 2008. SNI 6128:2008. Beras. Jakarta.

Khairul Imam Affandi,Hamid Ahmad, dan Tasliman. 2014. Uji Kinerja Mesin Pemecah Kulit Gabah dengan Variasi Jarak Rol Karet dan Dua Varietas Gabah pada Rice Milling Unit (RMU). Jurnal Universitas Jember.

Mulyoto, 2000.Mesin-Mesin Pertanian. CV. Yasaguna. Jakarta

Nofriadi. 2007. Rancang Bangun Mesin Penggiling Padi Skala Kecil. Jurnal Teknik Mesin. Vol. 4, No. 2: 1-8

Patiwiri AW. 2006. Teknologi Penggilingan Padi. Gramedia Pustaka Utama, Jakarta.
Prihadi,W. S. Dewi, dan Jumali. 2009. Identifikasi Karakteristik dan Mutu Beras di Jawa Barat. Jurnal Penelitian Pertanian Tanam Pangan Vol. 28 No. 12009.

Rokhani, H. 2007. Gerakan Nasional Penurunan Susut Pascapanen Suatu Upaya Menanggulangi Krisis Pangan.Agrimedia volume 12.Hal : 21- 30.

Soerjandoko. 2010. Teknik Pengujian Mutu Beras Skala Laboratorium. Buletin Teknik Pertanian Vol. 15, No. 2, 2010: 44-47.

Sri Widowati. 2001. Pemanfaatan Hasil Samping Penggilingan Padi. BuletinAgroBio.Vol 4, No. 1, pp. 3338.

Sugiyono, A. 2004.Pemasaran Pertanian. UMM Press. Malang.

Sugondo, Suwandi. 2002. Perkembangan teknologi penggilingan padi dan pengaruhnya terhadap peningkatan kualitas dan rendemen beras. Diskusi Teknis Kinerja Sistem Penggilingan Padi. Badan Litbang Pertanian. Jakarta, 18 Juli 2002.

Suismono, 2002.Standardisasi mutu untuk perdagangan beras di Indonesia. Majalah Pangan 39(XI): 37-47.

Tjahjohutomo, R., Handaka, Harsono dan T.W. Widodo. 2004. Pengaruh Konfigurasi Mesin Penggilingan Padi Rakyat terhadap Rendemen dan Mutu Beras Giling. Jurnal Enjiniring Pertanian Valume II No.1 April 2004.

Waries, A. 2006. Teknologi Penggilingan Padi. Gramedia Pustaka Utama, Jakarta. 